\title{
Construction of in situ degradation bacteria of corn straw and analysis of its degradation efficiency
}

Xiujie Gong ${ }^{1,2}$, Hongtao Zou ${ }^{1 *}$, Chunrong Qian², Yang Yu², Yubo Hao², Liang Li², Qiuju Wang ${ }^{3}$, Yubo Jiang ${ }^{2}$ and Juntao $\mathrm{Ma}^{4}$

\begin{abstract}
Purpose: The highly efficient degradation bacteria were selected from the humus from the very cold straw in China for many years to construct the in situ degradation bacteria, and the degradation efficiency of corn straw was determined by process optimization.

Methods: According to the main components of corn straw, through morphological, physiological, and biochemical screening, three highly efficient complementary degradation strains were selected to construct the compound flora, and the degradation efficiency was analyzed by Fourier transform infrared spectrometer, field emission scanning electron microscope, and X-ray diffractometer.
\end{abstract}

Result: The corn straw selected in this paper is mainly composed of cellulose (31.99\%), hemicellulose (25.33\%), and lignin (14.67\%). Through the determination of enzyme activity, strain Streptomyces sp. G $1^{\top}$ has high decomposition ability to cellulose and hemicellulose but weak utilization ability to lignin; strain Streptomyces sp. $G 2^{\top}$ has the strongest decomposition ability to cellulose and hemicellulose among the three strains. The decomposition ability of strain Streptomyces sp. G3 $3^{\top}$ to lignin was the strongest among the three strains. Therefore, by compounding the three strains, the decomposition ability has been greatly improved. The optimal process conditions obtained by single factor and response surface method are as follows: $\mathrm{pH}$ is 7 , temperature is $30^{\circ} \mathrm{C}$, inoculation amount is $5 \%$, rotational speed is $210 \mathrm{rpm}$, and the weight loss rate of straw is $60.55 \%$ after decomposing for 7 days. A large amount of degradation of corn straw can be seen by Fourier transform infrared spectrometer, field emission scanning electron microscope, and X-ray diffractometer.

Conclusion: Streptomyces sp. G1 $1^{\top}$, Streptomyces sp. G2 ${ }^{\top}$, and Streptomyces sp. G3 ${ }^{\top}$ screened from straw humus in very cold areas were used to construct in situ degradation bacteria, which had good straw degradation activity and had the potential to be used for straw treatment in cold areas after harvest. This characteristic makes the complex bacteria become a strong competitive candidate for industrial production, and it is also an effective biotechnology in line with the current recycling of resources.

Keywords: Corn straw, In situ degrading bacteria, Strain identification, Flora construction, Degradation efficiency

\footnotetext{
*Correspondence: zouhongta02001@163.com

${ }^{1}$ College of Land and Environment, Shenyang Agricultural University, No.

120, DongLing Road, Shenhe District, Shenyang 110866, People's Republic of

China

Full list of author information is available at the end of the article
}

(c) The Author(s). 2020 Open Access This article is licensed under a Creative Commons Attribution 4.0 International License, which permits use, sharing, adaptation, distribution and reproduction in any medium or format, as long as you give appropriate credit to the original author(s) and the source, provide a link to the Creative Commons licence, and indicate if changes were made. The images or other third party material in this article are included in the article's Creative Commons licence, unless indicated otherwise in a credit line to the material. If material is not included in the article's Creative Commons licence and your intended use is not permitted by statutory regulation or exceeds the permitted use, you will need to obtain permission directly from the copyright holder. To view a copy of this licence, visit http://creativecommons.org/licenses/by/4.0/. 


\section{Introduction}

China, as a traditional agricultural country in the world, produces more than 600 million tons of straw every year. Such a huge resource is often incinerated by traditional methods, resulting in a large amount of smoke causing serious haze problems, while carbon dioxide is emitted directly into the atmosphere, leading to global warming (Yin et al. 2010).

Straw is mainly composed of cellulose, which is a kind of renewable organic molecules with the most abundant reserves on the earth (Klemm et al. 2005). It is a promising method to decompose it by cellulase produced by microorganisms (Sukumaran et al. 2005; Octave and Thomas 2009). This enzyme is widely used in textile industry, pharmaceutical industry, food industry, biofuel, pollution control, and feed industry (Sreena et al. 2016; Aarti et al. 2018; Thomas et al. 2018; Sreena and Sebastian 2018). Keeping crop straw in the field can supplement soil organic matter and improve soil fertility. However, in cold areas, due to low temperature and slow straw decomposition, crop straw retention is often complained of the negative impact of crop straw accumulation on crop growth and yield. The accumulation of straw will affect plant growth, nutrient availability, soil temperature, water infiltration, and evaporation, as well as the population of diseases and insect pests. At present, the research on biodegradation of corn straw at home and abroad is mainly focused on the following aspects:

\section{Straw returning to the field}

Through various forms of corn straw returning technology, although to a certain extent, it can increase soil organic matter, improve soil physical and chemical properties, and reduce the loss of phosphorus and potassium nutrients in straw. But there are also some problems that affect its wide application (Zhang 2009). First, because the corn straw is mainly composed of lignocellulose, if it is not treated, it is difficult to be degraded by microorganisms in the natural field, so that the straw is decomposed and transformed by microorganisms in the soil for a long time, and the soil fertility effect will not be achieved immediately. It even affects the farming of crops in the next season, which is not attractive to farmers (Chen et al. 2002; Xu et al. 2001). Second, due to the degradation of straw in the field that requires a certain ratio of carbon to nitrogen, resulting in competition for fertilizer between straw and crops, which may affect crop growth, resulting in a certain degree of yield reduction, so that farmers resist it. In addition, in the winter paddy field in the south, after the corn straw is returned to the field, the content of methane released from the paddy field will be doubled, which has attracted great attention of the environmental circle (Sabine et al. 2001; Liou et al. 2003; Lu et al. 2010).

\section{Straw feed}

Corn straw is a kind of inferior roughage, which is mainly due to its high fiber content, low crude protein and mineral content, and lack of vitamins A, D, and E, cobalt, copper, sulfur, sodium, selenium, and other mineral elements necessary for animal growth. Energy is very low. Moreover, the high degree of silicification of corn straw cell wall, especially the high content of insoluble silicon, further limits the degradation and utilization of corn straw cellulose by rumen microorganisms. Due to these reasons, the animal feed intake and nutrient digestibility of corn straw feed are affected, so the value of corn straw as feed is small and its application is limited (Han et al. 2002).

\section{Straw energy}

In China's rural areas, cooking and heating with stalks instead of coal has always existed, and before the 1990s, this method consumed more than $60 \%$ of the total straw (Zhong et al. 2003; Qiang 2006). However, the burning value of straw is only about $10 \%$, and the combustion heat energy of corn straw is far lower than that of wheat, corn, soybean, and other crops. Using straw as fuel not only causes a lot of waste of energy, but also produces serious environmental pollution. With social development and the improvement of people's living standards, most of them are gradually being replaced by coal, gas, or electricity. At present, they account for only $20 \%$ in poor areas, $5 \%$ in general areas, and zero consumption around cities or in relatively affluent areas (Zhang 2009). This makes the problem of excess straw more prominent, resulting in direct burning and disposal of straw in the field.

Due to the demand of farmers for efficient, clean, and convenient energy, a number of straw energy utilization technologies have been carried out at home and abroad. At present, the main ways of energy conversion of corn straw are straw direct combustion heating technology, straw gasification central gas supply technology, straw ethanol production, straw fermentation biogas technology, and so on (Liu et al. 2008). However, there are some problems in these methods, such as straw central direct combustion heating is difficult to be widely used because of its high operation cost, straw gasification is only in the experimental stage, and there are some problems, such as low gas production rate, high cost, and difficult gas purification. Due to the limitation of its technological level, cellulosic ethanol is still in the stage of industrialization which needs national financial support and subsidy, and it is still a long way from large-scale application. Using straw as fermentation raw material to produce biogas, there are some problems, such as low straw degradation rate, poor input-output efficiency, crusting in the pond, and difficulty to discharge (Chen 2002). 


\section{Straw papermaking}

Plant fiber is the basic raw material for the development of pulp and paper industry. According to international statistics, wood used in the world paper industry accounts for more than $90 \%$ of pulping fiber raw materials (excluding waste paper). Among the raw materials of pulping fiber in China, the proportion of grass and other non-wood raw materials is very prominent, and it is the largest producer of straw pulp in the world. At present, the main grass materials used are corn straw, wheat straw, Reed, awn stalk, bamboo, bagasse, hemp, cotton, and so on. However, the collection and transportation of household-produced corn straw for papermaking is limited, and the environmental pollution of papermaking still needs to be solved (Zhang 2009).

\section{Industrial raw materials}

At present, the industrial utilization of corn straw is mainly used in the material industry, and its utilization modes include straw scrap board, straw medium-density fiberboard, straw lightweight wall lining materials, straw packaging pillows, and so on. Using corn straw as building materials can not only partially replace bricks, wood, and other materials, but also effectively protect forest resources. However, as the modern utilization of straw in industry has just started in our country, it still needs a long time to explore in terms of technology and marketing (Gao 2006).

To sum up, direct combustion as fuel, roughage, various ways of returning straw to the field, and a large number of field burning are still the main treatment methods of corn straw, resulting in serious environmental pollution. Although corn straw is actively developing other ways of utilization, many straw energy utilization technologies are not mature enough; their application and promotion are not extensive, and the cost of transporting straw to other places by large-scale machinery is too high to solve the problem of straw surplus (Sukumaran et al. 2005). If we can use microorganisms to degrade and transform corn straw, it will greatly promote the problem of straw returning to the field and the development of other application methods, and at the same time greatly reduce the environmental pollution caused by straw incineration. It is also of positive significance to alleviate the excessive carbon dioxide emissions and air pollution crisis in the world today.

Therefore, it is particularly important to study the degradation and utilization of straw, which is based on the contradiction between agricultural production and environmental protection (Russell et al. 2009; Watanabe and Tokuda 2010). In recent years, many scholars have screened some strains with the ability of corn straw degradation, but most of them generally have the problem of low enzyme activity. And the screening of some strains only takes the degradation of cellulose as the screening index, ignoring whether the strain has the ability to degrade the other two main components (hemicellulose and lignin) in corn straw. As the main component of corn straw is cellulose, in addition, it also includes hemicellulose, lignin, wax, a small amount of structural proteins, and some mineral elements, which form a strong tissue, which greatly reduces the utilization rate of cellulose. Therefore, it is still necessary to design a more comprehensive and reasonable screening method to obtain highly efficient degradation strains of corn straw.

\section{Materials and methods}

\section{Collection of humus soil}

In order to obtain in situ strains that can decompose corn straw in alpine areas, these soils were collected from the humus of straw returned to the field for many years in Heihe City, Heilongjiang Province. The soil was collected in Wudalianchi $\left(48.17{ }^{\circ} \mathrm{N}, 126.35^{\circ} \mathrm{E}\right)$, Xunke $\left(47.58^{\circ} \mathrm{N}, 129.17^{\circ} \mathrm{E}\right)$, and Bei'an $\left(47.35^{\circ} \mathrm{N}, 127.51^{\circ} \mathrm{E}\right)$. A total of 15 soil samples were collected, 5 from each location.

\section{Screening of degrading bacteria}

The soil samples were naturally dried in the shade, ground into fine powder in a mortar, put into a triangular bottle, added an appropriate amount of sterilized glass beads, put into an air oscillator $180 \mathrm{rpm}$, and shaken for half an hour, then diluted and coated on ISP2 medium (glucose $0.4 \%$, malt extract $1 \%$, yeast extract 0.4\%, Ager 2\%, pH 7.0-7.4).

\section{Cultivation of microorganisms}

The strains with fast colony growth and good growth state were cultured in ISP2 medium and inverted in $28^{\circ} \mathrm{C}$ incubator.

\section{Identification of the target strain}

The above strains were pure cultured, passed on for 3-5 generations, and stained with Congo red, and three strains with larger transparent circle were selected for the following experiments (Teather and Wood 1982).

\section{Pretreatment of straw}

The harvested corn straw was dried to a constant weight, crushed with a traditional Chinese medicine grinder, and sifted through a 40-mesh sieve.

\section{Determination of main components of straw}

The determination of cellulose, lignin, hemicellulose, and ash in corn straw refers to VanSoest washing method. 


\section{Determination of enzyme activity}

\section{Determination of glucose content by DNS}

Twenty-four clean and dried 5-mL test tubes were placed on the test tube rack, sorted from 0 to 7 , and marked, with each number corresponding to 3 test tubes. As shown in Tables 2, 3, 4, and 5, glucose solutions with different concentration gradients are added, and the volume is replenished to $2 \mathrm{~mL}$ with $\mathrm{ddH}_{2} \mathrm{O}$ accordingly. Add the same amount of DNS solution, shake well, and put the test tube into boiling water for $10 \mathrm{~min}$. The mouth of the test tube is plugged with cotton to prevent it from boiling. After cooling to room temperature, the $0.5 \mathrm{~mL}$ reaction solution was fully

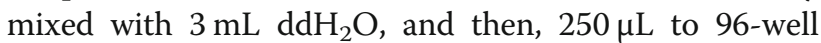
plate was extracted from the diluted solution, and the absorbance value was determined at $540 \mathrm{~nm}$ (Denison and Koehn 1977).

\section{Determination of FPA enzyme activity}

The filter paper strip was accurately weighed $50 \mathrm{mg}$. In order to increase the contact area with the crude enzyme extracted from the straw system, the filter paper strip was cut and added to the centrifuge tube of $4.5 \mathrm{~mL}$ as the reaction substrate. Citric acid buffer and crude enzyme solution were added with a total volume of $2 \mathrm{~mL}$ and a ratio of 1:1. After setting the parameter of $1000 \mathrm{rpm}$ for $2 \mathrm{~min}$, the fermentation product was fully centrifuged to obtain the crude enzyme solution. Fully vibrate with an oscillator, and then bathe in water at $60^{\circ} \mathrm{C}$ for $60 \mathrm{~min}$. Set the parameter $12,000 \mathrm{rpm}$ for $5 \mathrm{~min}$, remove the bottom flocs after centrifugation, take the supernatant of $1 \mathrm{~mL}$, add $1.5 \mathrm{~mL}$ DNS solution and $1 \mathrm{~mL} 0.05 \mathrm{~mol} / \mathrm{L}$ citric acid buffer with $\mathrm{pH} 5.0$ of $1 \mathrm{~mL} 0.05 \mathrm{~mol} / \mathrm{L}$, and boil for 5 min after shaking. After cooling, take the $0.5 \mathrm{~mL}$ reaction solution and $3 \mathrm{~mL} \mathrm{ddH}_{2} \mathrm{O}$ repeatedly, extract $250 \mu \mathrm{L}$ from each centrifuge tube and add it to the 96-well plate, determine the absorbance value at 540 $\mathrm{nm}$, and convert it into enzyme activity according to the formula.

\section{Determination of exoglucanase activity}

Precisely extract $1 \mathrm{~mL} 1 \%$ crystalline cellulose solution and add it to the centrifuge tube of $4.5 \mathrm{~mL}$ as the reaction substrate. Citric acid buffer and crude enzyme solution were added; the total volume of them was 2 $\mathrm{mL}$; the ratio was $1: 1$. After setting the parameter of $1000 \mathrm{rpm}$ for $2 \mathrm{~min}$, the fermentation product was fully centrifuged to obtain the crude enzyme solution. Fully vibrate with an oscillator and then bathe in water at $60^{\circ} \mathrm{C}$ for $60 \mathrm{~min}$. Set the parameter 12,000 $\mathrm{rpm}$, the time is $5 \mathrm{~min}$; after high-speed centrifugation, the floc settles to the bottom, take $1 \mathrm{~mL}$ supernatant, add $1.5 \mathrm{~mL}$ DNS solution and $1 \mathrm{~mL} 0.05 \mathrm{~mol} / \mathrm{L}$ citric acid buffer with $\mathrm{pH}$ 5.0. After shaking, boil for $5 \mathrm{~min}$; after cooling, take the $0.5 \mathrm{~mL}$ reaction solution

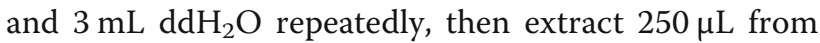
the centrifugal tube, and add it to the 96-well plate in turn, determine the absorbance value at $540 \mathrm{~nm}$, and convert it into enzyme activity according to the formula.

\section{Determination of endoglucanase activity}

Precisely extract $1 \mathrm{~mL} 1 \%$ sodium carboxymethyl cellulose solution and add it to the centrifuge tube of $4.5 \mathrm{~mL}$ as the reaction substrate. Citric acid buffer and crude enzyme solution were added; the total volume of them was $2 \mathrm{~mL}$; the ratio was 1:1. After setting the parameter of $1000 \mathrm{rpm}$ for $2 \mathrm{~min}$, the fermentation product was fully centrifuged to obtain the crude enzyme solution. Add DNS solution of $1.5 \mathrm{~mL}$ and citric acid buffer solution of $1 \mathrm{~mL} 0.05 \mathrm{~mol} / \mathrm{L}$ with pH 5.0 and boil for $5 \mathrm{~min}$ after shaking. After cooling, take $0.5 \mathrm{~mL}$ reaction solution and $3 \mathrm{~mL} \mathrm{ddH}_{2} \mathrm{O}$ repeatedly, extract $250 \mu \mathrm{L}$ from each centrifuge tube, and add it to 96-well plate in turn. The absorbance value is determined at $540 \mathrm{~nm}$, and the enzyme activity is converted into enzyme activity according to the formula.

\section{$\beta$-1,4-determination of glucanase activity}

Precisely extract $1 \mathrm{~mL} 1 \%$ salicylic solution and add it to the centrifuge tube of $4.5 \mathrm{~mL}$ as the reaction substrate. Citric acid buffer and crude enzyme solution were added; the total volume of them was $2 \mathrm{~mL}$; the ratio was 1:1. After setting the parameter of $1000 \mathrm{rpm}$ for $2 \mathrm{~min}$, the fermentation product was fully centrifuged to obtain the crude enzyme solution. DNS solution of $1.5 \mathrm{~mL}$ and citric acid buffer solution of $1 \mathrm{~mL} 0.05 \mathrm{~mol} / \mathrm{L}$ with $\mathrm{pH}$ 5.0 were added and boiled for $5 \mathrm{~min}$ after shaking. After cooling, the $0.5 \mathrm{~mL}$ reaction solution was repeatedly

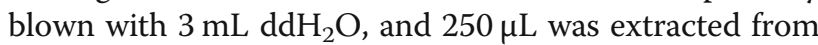
each centrifuge tube and added to the 96-well plate in turn. The absorbance value was determined at $540 \mathrm{~nm}$ and transformed into enzyme activity according to the formula.

The production of $1 \mu \mathrm{g}$ glucose per $1 \mathrm{~min}$ is defined as a unit of enzyme activity. Three parallel samples were set up in the above enzyme activity determination experiments, and finally, the average value was taken (Cao 2010).

\section{Verification of complementarity}

The enzyme activities of cellulose, hemicellulose, and lignin of the three strains were determined to observe whether the three strains could degrade corn straw comprehensively (Sun et al. 2016). 


\section{Single factor experiment and response surface optimization}

The influence factors on the weight loss rate of corn straw were screened by six factors, such as initial $\mathrm{pH}$ value, fermentation temperature, inoculation amount, fermentation time, loading quantity, and rotational speed. A series of single factor experiments were carried out to explore the effect of fermentation conditions on the degradation of corn straw. The experimental design of response surface was carried out by using the DesignExpert software, and the best fermentation conditions were determined according to the analysis of the results.

\section{Degradation efficiency analysis}

The degradation efficiency was analyzed by Fourier transform infrared spectrometer (Thermo Fisher Scientific Nicolet 6700), field emission scanning electron microscope (QUANTA FEG 250), and X-ray diffractometer (UltimaIV SmartLab).

\section{Statistical analysis}

The standard error $( \pm)$ of the average is calculated through three measurements using Microsoft Office Excel 2010.

\section{Results and discussion}

\section{Determination of main components in corn straw}

The corn straw was crushed into powder, and its composition was determined after sifting through 40 mesh. According to the experimental results, it can be seen that the main components of corn straw are cellulose, namely cellulose, hemicellulose, and lignin (Table 1).

\section{Drawing glucose standard curve by DNS method}

The regression equation is $y=0.6817 \mathrm{x}-0.0236, R^{2}=$ 0.9989 , and the curve can be used (Fig. 1).

\section{Determination of cellulase activity in continuous fermentation system of strain}

In order to verify the ability of strains Streptomyces sp. $\mathrm{G1}^{\mathrm{T}}$, Streptomyces sp. $\mathrm{G} 2^{\mathrm{T}}$, and Streptomyces sp. $\mathrm{G} 3^{\mathrm{T}}$ to decompose and utilize corn straw, the cellulase activity levels of the three strains were determined, and the fermentation period was set to 24 days. First of all, the straw samples were processed into small segments by a miniature plant sample grinder, and the straw powder

Table 1 Main components of corn straw

\begin{tabular}{ll}
\hline Components & Content (\%) \\
\hline Cellulose & 31.99 \\
Hemicellulose & 25.33 \\
Lignin & 14.67 \\
Ash & 9.81 \\
\hline
\end{tabular}

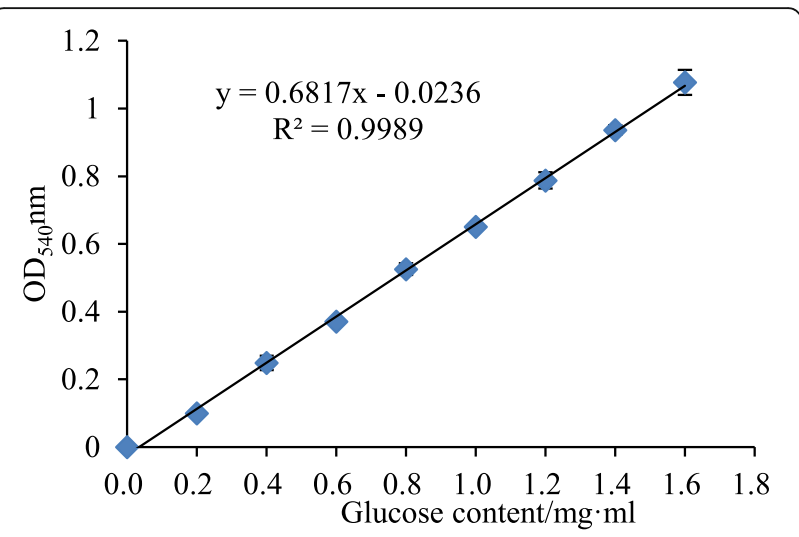

Fig. 1 Standard curve of dextrose (the DNS method)

was obtained after 40 mesh sieving, and then used to prepare the fermentation medium. The purified strains were picked into ISP2 medium and prepared into seed liquid for spare. When the strain was added to the fermentation medium according to the proportion of 3\% $(\mathrm{v} / \mathrm{w})$, it was observed that the medium was brown, and the culture medium gradually appeared bubbles with the increase of fermentation time. The cellulase activity was determined every 3 days when the parameters were set at $28^{\circ} \mathrm{C}$ and $180 \mathrm{rpm}$.

The cellulase activity of strains Streptomyces sp. $\mathrm{G1}^{\mathrm{T}}$, Streptomyces sp. G2 ${ }^{\mathrm{T}}$, and Streptomyces sp. G3 ${ }^{\mathrm{T}}$ on the 3rd, 6th, 9th, 12th, 15th, 18th, 21st, and 24th day of corn straw fermentation was determined respectively (Figs. 2, 3, and 4).

\section{Verification experiment on functional complementarity of flora}

Through the fermentation of corn straw with single strain, compared with the fermentation of compound bacteria, it was found that strain Streptomyces sp.G1 ${ }^{\mathrm{T}}$ had higher ability to decompose cellulose and

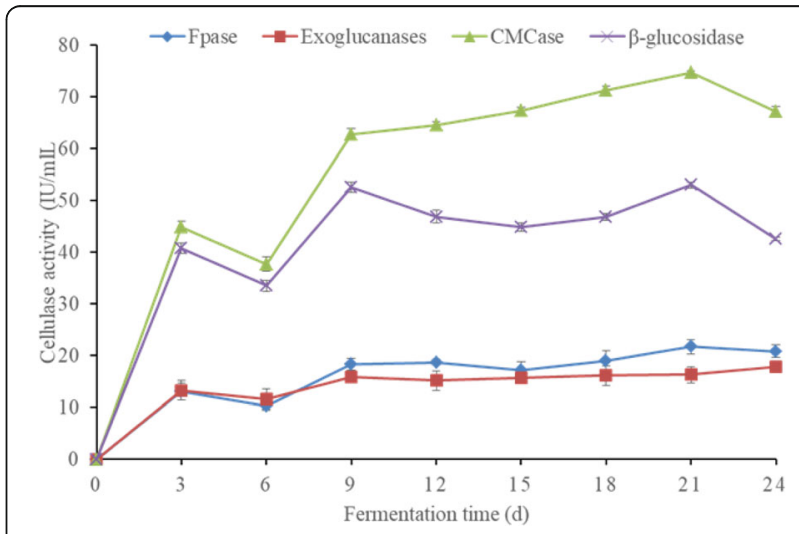

Fig. 2 Cellulose enzyme activity measurement size of strain Streptomyces sp. G1 ${ }^{\top}$ 


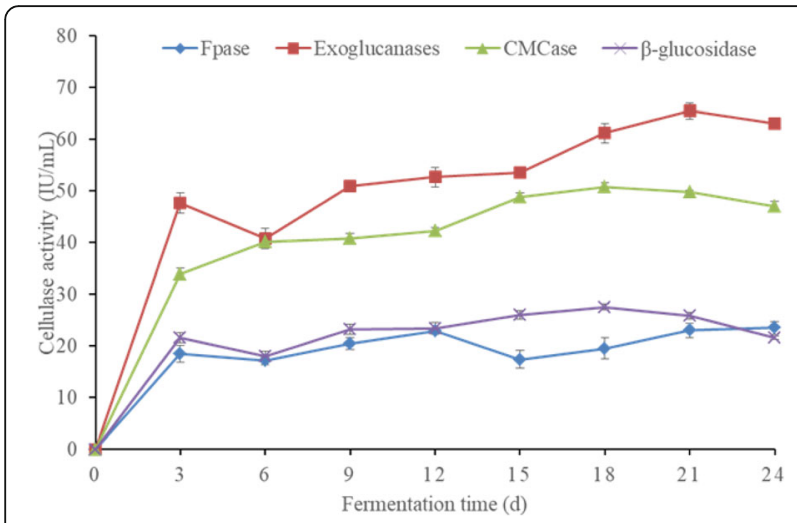

Fig. 3 Cellulose enzyme activity measurement size of strain Streptomyces sp. G2 ${ }^{\top}$

hemicellulose but weak ability to utilize lignin, strain Streptomyces sp. G2 ${ }^{\mathrm{T}}$ had the strongest ability to decompose cellulose and hemicellulose, and strain Streptomyces sp.G3 ${ }^{\mathrm{T}}$ had the strongest ability to decompose lignin. Compared with the fermentation effect of the compound bacteria, it can be seen that the compound bacteria have obvious advantages in the decomposition ability of cellulose, hemicellulose, and lignin, which also shows that the compound of different strains can form complementary capacity; the decomposition effect is better than that of a single strain (Fig. 5). In the follow-up experiment, the compound flora will be constructed, and the fermentation conditions will be optimized.

\section{Single factor experiment on fermentation of compound bacteria}

In this study, the effects of six factors, such as initial $\mathrm{pH}$, temperature, inoculation amount, time, loading capacity, and rotational speed, on straw weight loss were investigated, and single factor experiments were carried out to optimize the fermentation conditions (Roy and Sen 2013).

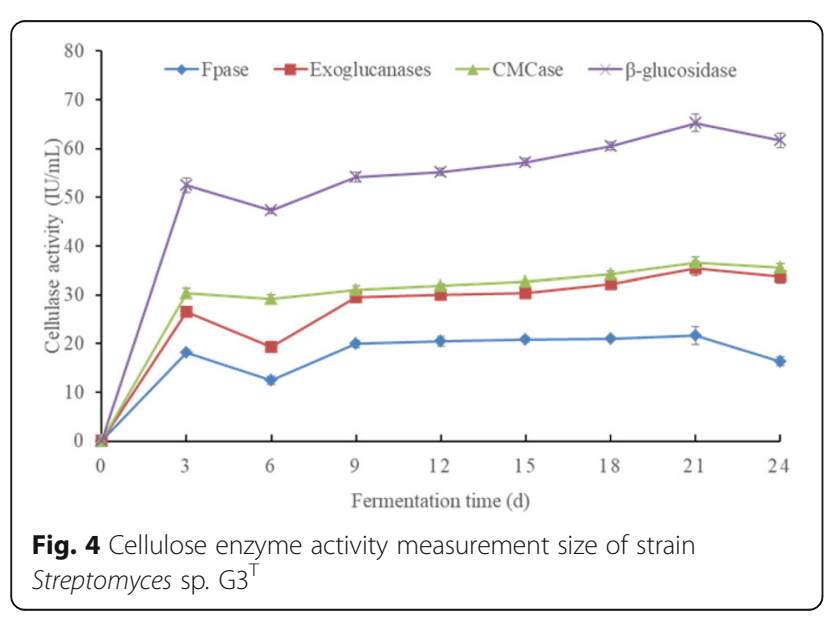

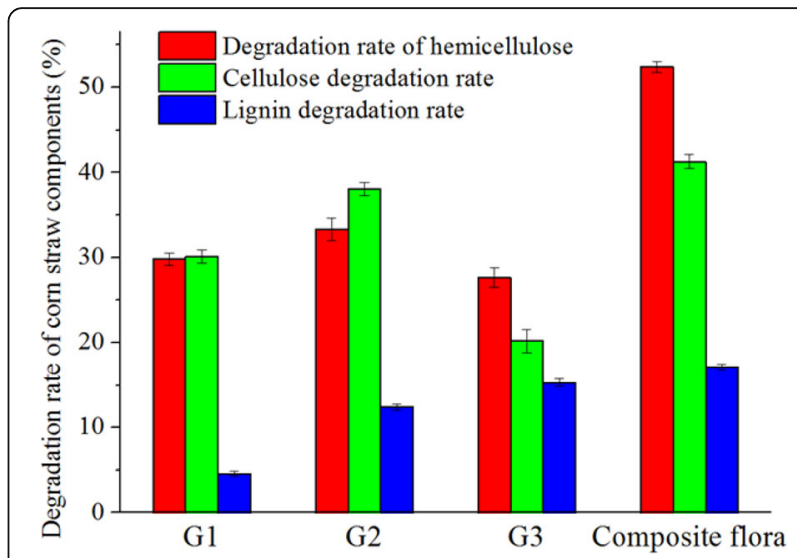

Fig. 5 Composite flora function complementary validation experiments

By studying the effect of initial $\mathrm{pH}$ on the weight loss rate of corn straw (Fig. 6), it was found that with the gradual increase of initial $\mathrm{pH}$, the weight loss rate of corn straw increased at first and then decreased. In the lower range of $\mathrm{pH}$, the weight loss rate of corn straw is low. When the $\mathrm{pH}$ value reaches 7.5 , the maximum weight loss rate of corn straw reaches $54.87 \%$. When the $\mathrm{pH}$ is higher than 7.5, the weight loss rate of corn straw decreases gradually. The analysis shows that the compound flora is more beneficial to the growth, reproduction, and metabolic activities of microorganisms in the neutral environment (Younis et al. 2010; Bai et al. 2012).

By studying the effect of temperature on the weight loss rate of corn straw (Fig. 7), it was found that the weight loss rate of corn straw increased at first and then decreased with the increase of temperature. When the temperature is in the range of $22-28^{\circ} \mathrm{C}$, the weight loss rate of corn straw is low; when the temperature reaches $28^{\circ} \mathrm{C}$, the maximum weight loss rate of corn straw reaches $57.29 \%$; when the temperature is higher than $28^{\circ} \mathrm{C}$, the weight loss rate of corn straw decreases

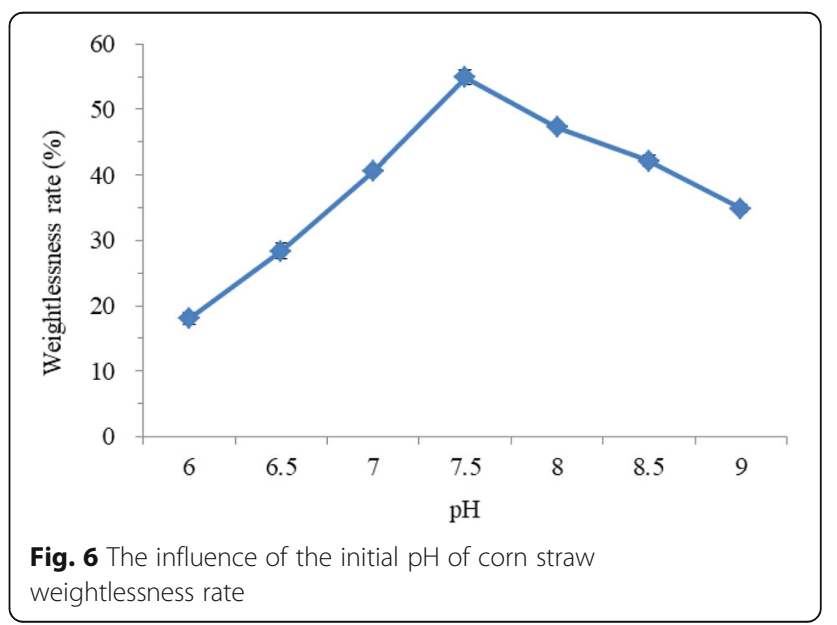


gradually. The analysis showed that when the temperature was lower, the growth and metabolism of microorganisms were slower, which affected the degradation rate of straw, while when the temperature was higher, the yield and activity of microbial enzymes decreased, thus affecting the degradation rate (Aiba et al. 1973).

By studying the effect of the inoculation volume of compound strains on the degradation rate of corn straw (Fig. 8), it was found that the weight loss rate of corn straw increased at first and then gently with the increase of inoculation volume. When the inoculation amount is in the range of $1-3 \%$, the weight loss rate of corn straw increases significantly; when the inoculation volume reaches $3 \%$, the maximum weight loss rate of corn straw reaches 57.4\%; and when the inoculation volume is higher than $3 \%$, the weight loss rate of corn straw basically does not change. The analysis shows that when the inoculation volume is low, the main factor affecting the degradation rate is the low content of cellulase produced by the bacteria, which affects the degradation rate of corn straw; while when the inoculation volume is higher than $3 \%$, the nutrients in the culture medium are quickly consumed, resulting in a decrease in the yield and activity of the enzyme, thus affecting the degradation rate.

By studying the effect of fermentation time of compound strain on the degradation rate of corn straw (Fig. 9), it was found that the weight loss rate of corn straw increased at first and then tended to be stable with the increase of fermentation days; when the fermentation days were 1-7 days, the weight loss rate of corn straw increased linearly and reached the maximum value of $59.79 \%$ on 7 days; with the continuous increase of fermentation days, the weight loss rate of corn straw increased slightly, but changed little. The analysis showed that the nutrients were almost used up in 7 days, which affected the growth and

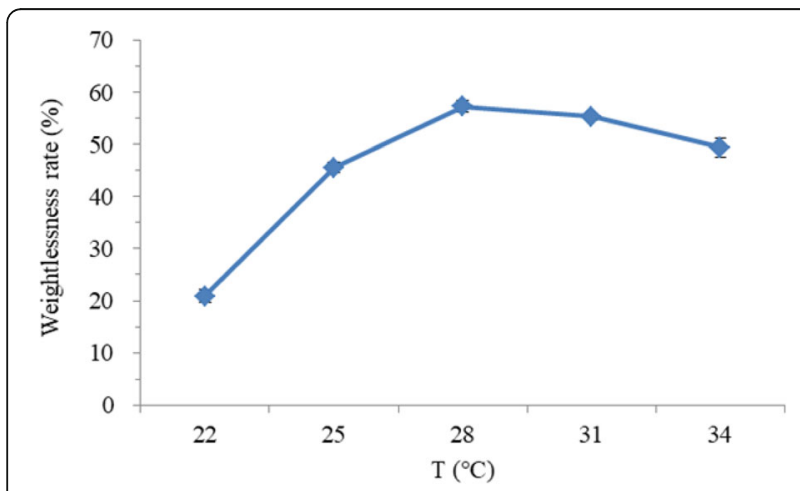

Fig. 7 The effect of temperature of corn straw weightlessness rate

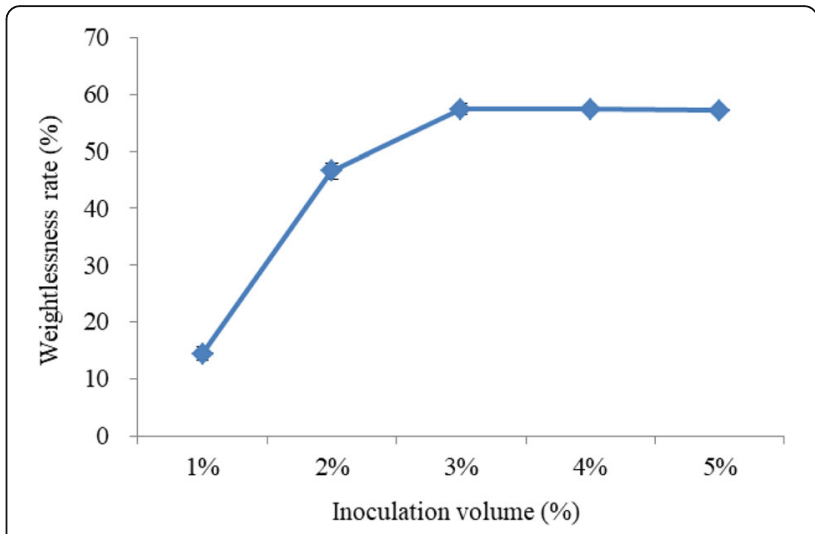

Fig. 8 The effect of inoculation volume of corn straw weightlessness rate

metabolism of the complex bacteria, thus affecting the yield of enzymes and then the degradation rate.

Through the study of the effect of loading amount on the degradation rate of corn straw (Fig. 10), it was found that the degradation rate of corn straw decreased gradually with the increase of loading amount (Brock and Madigan 1988). When the loading amount is in the range of $10-30 \%$, the weight loss rate of corn straw decreases slowly, but the weight loss rate of corn straw decreases linearly with the increase of loading amount. The analysis shows that with the increase of loading quantity, the unit contact area between material and enzyme decreases, which affects the weight loss rate of corn straw (Wanderley et al. 2004).

Through the study of the effect of shaking speed on the degradation rate of corn straw (Fig. 11), it was found that the weight loss rate of corn straw increased and then decreased with the increase of rotating speed. When the rotational speed is in a lower range, the weight loss rate of corn straw is lower, and when the rotational speed reaches $180 \mathrm{rpm}$, the maximum degradation rate of corn straw is $57.84 \%$. With the increase of rotational speed, the degradation rate of corn straw

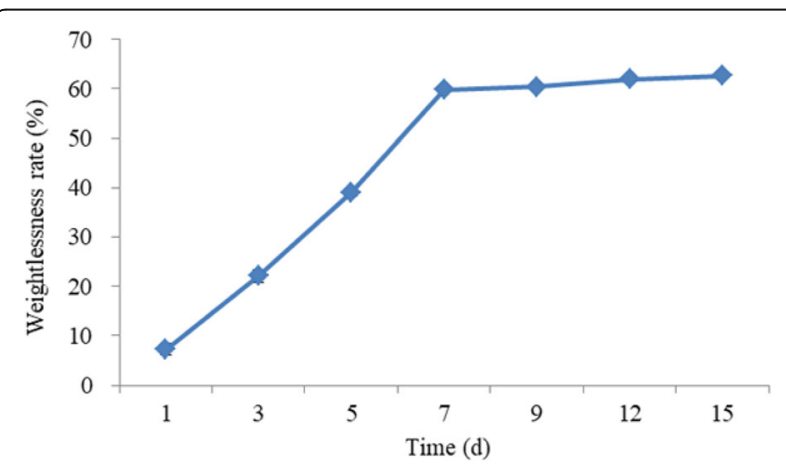

Fig. 9 The effect of time of corn straw weightlessness rate 


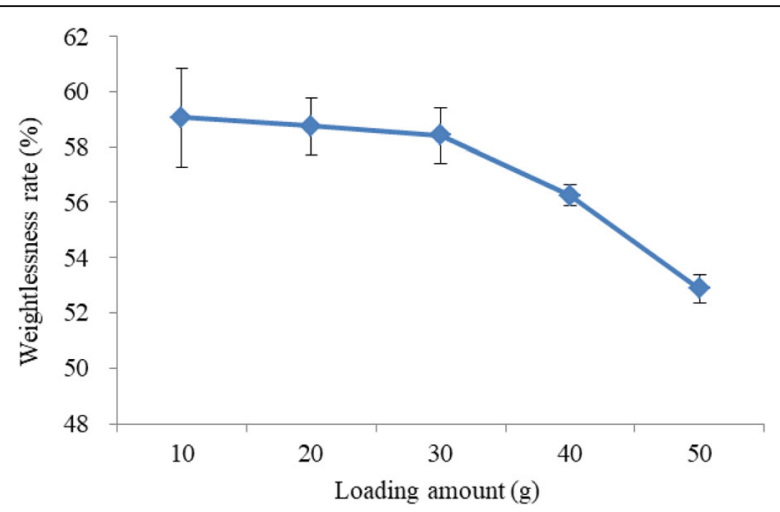

Fig. 10 The effect of loading amount of corn straw weightlessness rate

decreases gradually. The analysis shows that the rotational speed affects the oxygen supply in the fermentation process; when the rotational speed is low, it cannot provide sufficient oxygen, which affects the degradation rate of corn straw; when the rotational speed is higher than $180 \mathrm{rpm}$, it can inhibit the growth and reproduction of bacteria.

For the sake of economy and practical operation, 7 days of fermentation was selected as the optimal culture time, $30 \mathrm{~g}$ was selected as the best loading quantity, and other factors were analyzed and optimized by response surface.

\section{Response surface experiment}

According to the single factor experiment, the optimization factors were determined as $\mathrm{pH}$, temperature, inoculation volume, and shaking speed, and the response surface experiment was carried out.

Using the Design-expert8.0 software to carry on the multiple regression fitting to the experimental data, the binary multiple regression model of corn straw weight

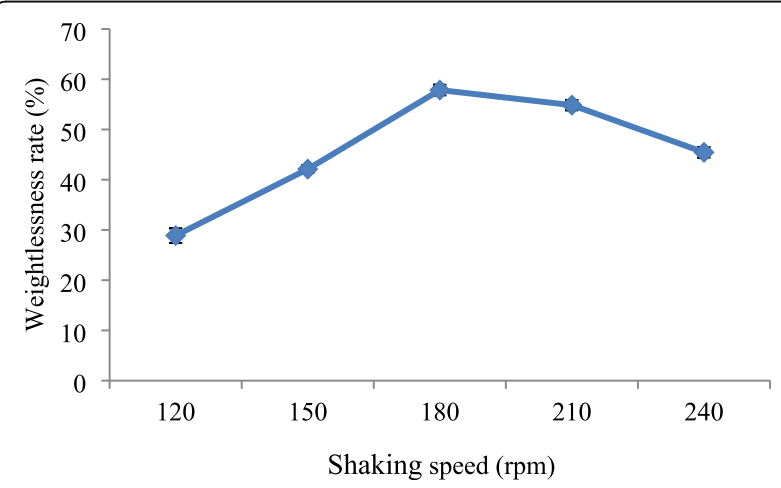

Fig. 11 The effect of shaking speed of corn straw weightlessness rate loss rate on $\mathrm{pH}$, temperature, inoculation volume, and shaking speed was obtained (Tables 2 and 3).

Weight loss rate of corn straw

$$
\begin{aligned}
= & 57.43+0.26 \mathrm{~A}+0.83 \mathrm{~B}+1.55 \mathrm{C}+1.23 \mathrm{D}-1.70 \mathrm{AB} \\
& -2.44 \mathrm{AC}-1.33 \mathrm{AD}+0.085 \mathrm{BC}+0.50 \mathrm{BD}+1.32 \mathrm{CD} \\
& -2.78 \mathrm{~A}^{2}-1.96 \mathrm{~B}^{2}-1.16 \mathrm{C}^{2}-1.77 \mathrm{D}^{2}
\end{aligned}
$$

From the above analysis, we can see that the $P$ value of this model is less than 0.0001, indicating that it is extremely significant. This shows that the model fits well and can be used to optimize the degradation process of corn straw.

In the selected range, the effect relationship of each factor is $\mathrm{C}>\mathrm{D}>\mathrm{B}>\mathrm{A}$, that is, inoculation volume > shaking speed $>$ temperature $>\mathrm{pH}$; in which the $P$ values of $C, D, A B, A C, A^{2}, B^{2}$, and $D^{2}$ are all less than 0.01 , indicating that $C, D$, and the quadratic terms $A B$, $A C, A^{2}, B^{2}$, and $D^{2}$ have a very significant influence on the experiment, while the $P$ values of $\mathrm{B}, \mathrm{AD}, \mathrm{CD}$, and $\mathrm{C}^{2}$ are less than 0.05 , indicating a significant influence, as shown in Fig. 12.

Combining the results of the above single factor experiments and response surface analysis, Design-expert8 was used to select the optimal conditions of multiresponse values, and it was concluded that the optimal process parameters were $\mathrm{pH} 7.07$, temperature $30.19^{\circ} \mathrm{C}$, inoculation amount $5 \%$, and rotational speed $210 \mathrm{rpm}$. The predicted value of weight loss rate of corn straw is $60.62 \%$. Three groups of parallel experiments were designed to verify the accuracy of the design results. Considering the actual operation, $\mathrm{pH}$ was set to 7 , the temperature was set to $30^{\circ} \mathrm{C}$, the inoculation amount was set to $5 \%$, and the rotational speed was set to 210 $\mathrm{rpm}$ as the optimal process. Under these conditions, the average weight loss rate of corn straw was $60.55 \%$, which was basically consistent with the predicted value, indicating that the established regression equation could truly and accurately reflect the effects of the above four factors on corn straw degradation. It is proved that the process condition is feasible.

\section{Chemical analysis of biodegradation process of corn straw}

After continuous fermentation for 15 days, the cellulose content, hemicellulose content, and lignin content of corn straw were determined (Table 4).

\section{Fourier transform infrared spectroscopy}

The samples of corn straw at different stages of microbial degradation were scanned by FTIR in 4000 1200 $\mathrm{cm}^{-1}$ band, and the results are shown in Fig. 13 .

The infrared absorption peak shows that the hydroxyl stretching vibration of hydrogen bond is formed in 
Table 2 Response surface experiment design and result analysis

\begin{tabular}{|c|c|c|c|c|c|}
\hline \multirow[t]{2}{*}{ Stc } & \multirow{2}{*}{$\begin{array}{l}\mathrm{A} \\
\mathrm{pH}\end{array}$} & \multirow{2}{*}{$\begin{array}{l}\text { B } \\
\text { Temperature } /{ }^{\circ} \mathrm{C}\end{array}$} & \multirow{2}{*}{$\begin{array}{l}\text { C } \\
\text { Inoculation volume } / \%\end{array}$} & \multirow{2}{*}{$\begin{array}{l}\text { D } \\
\text { Shaking speed/rpm }\end{array}$} & \multirow{2}{*}{$\begin{array}{l}\text { Weightlessness } \\
\text { rate/\% }\end{array}$} \\
\hline & & & & & \\
\hline 1 & 7 & 28 & 4 & 150 & 50.27 \\
\hline 2 & 7 & 28 & 3 & 180 & 47.41 \\
\hline 3 & 8 & 28 & 5 & 180 & 53.37 \\
\hline 4 & 7.5 & 28 & 3 & 150 & 52.98 \\
\hline 5 & 8 & 31 & 4 & 180 & 52.27 \\
\hline 6 & 8 & 28 & 3 & 180 & 54.12 \\
\hline 7 & 7 & 31 & 4 & 180 & 55.94 \\
\hline 8 & 8 & 28 & 4 & 210 & 54.06 \\
\hline 9 & 7.5 & 31 & 3 & 180 & 54.08 \\
\hline 10 & 7.5 & 25 & 4 & 150 & 52.48 \\
\hline 11 & 7.5 & 31 & 5 & 180 & 56.57 \\
\hline 12 & 7.5 & 28 & 5 & 210 & 58.77 \\
\hline 13 & 7.5 & 25 & 4 & 210 & 52.16 \\
\hline 14 & 8 & 28 & 4 & 150 & 52.96 \\
\hline 15 & 7 & 28 & 5 & 180 & 56.42 \\
\hline 16 & 7.5 & 28 & 4 & 180 & 57.27 \\
\hline 17 & 7.5 & 28 & 4 & 180 & 57.38 \\
\hline 18 & 7.5 & 28 & 4 & 180 & 57.36 \\
\hline 19 & 7.5 & 25 & 3 & 180 & 53.46 \\
\hline 20 & 7.5 & 28 & 4 & 180 & 57.51 \\
\hline 21 & 7 & 28 & 4 & 210 & 56.69 \\
\hline 22 & 7 & 25 & 4 & 180 & 49.81 \\
\hline 23 & 7.5 & 28 & 4 & 180 & 57.63 \\
\hline 24 & 8 & 25 & 4 & 180 & 52.94 \\
\hline 25 & 7.5 & 31 & 4 & 210 & 54.60 \\
\hline 26 & 7.5 & 28 & 3 & 210 & 53.27 \\
\hline 27 & 7.5 & 25 & 5 & 180 & 55.61 \\
\hline 28 & 7.5 & 31 & 4 & 150 & 52.92 \\
\hline 29 & 7.5 & 28 & 5 & 150 & 53.21 \\
\hline
\end{tabular}

$3450-3400 \mathrm{~cm}^{-1}$ band; one part of hydroxyl group is carbohydrate; the other part is hydroxyl group containing water. In addition, the peak also includes absorption peaks stretching vibration of amino acid; $3010-2960 \mathrm{~cm}^{-1}$ band indicates symmetrical and antisymmetric stretching vibration peaks of $-\mathrm{CH}_{3},-\mathrm{CH}_{2}$, and $-\mathrm{CH}$ in carbohydrate, lignin, and aliphatic compounds. The $1740-1720 \mathrm{~cm}^{-1}$ band is the $\mathrm{C}=\mathrm{O}$ stretching vibration of ketones and carboxylic acid lipids, the $1680 \mathrm{~cm}^{-1}$ band is the hydrogen bond deformation vibration of water molecules and the antisymmetric stretching vibration of organic carboxylates, and the absorption peak of $1510-1500 \mathrm{~cm}^{-1}$ band is the aromatic ring skeleton vibration, which is mainly derived from lignin and other compounds containing benzene ring. The $1450-1420 \mathrm{~cm}^{-1}$ band is the deformation vibration of $-\mathrm{CH}_{2}$ connected by double bonds or carbonyl groups in lignin and aliphatic compounds and the absorption of inorganic $\mathrm{NH}^{+4}, \mathrm{NO}^{-3}$, and organic carboxylate $\mathrm{COO}^{-}$, while the absorption of $1330-1320 \mathrm{~cm}^{-1}$ band is the stretching vibration of $-\mathrm{OH}$, mainly carbohydrates.

It can be seen from Fig. 13 that after 2 days of fermentation, the intensity of absorption peaks near $3421 \mathrm{~cm}^{-1}$, $3008 \mathrm{~cm}^{-1}, 2368 \mathrm{~cm}^{-1}$, and $1601 \mathrm{~cm}^{-1}$ decreased partially, but the change was not significant, indicating that the relative contents of hydroxyl, methyl, and methylene decreased slightly, and the sources of these absorption peaks mainly included carbohydrates such as cellulose, hemicellulose, and some aliphatic compounds. Their changes indicate that carbohydrates such as cellulose and hemicellulose in corn straw may begin to decompose gradually. The absorption peak at $1510-1500 \mathrm{~cm}^{-1}$ band is the vibration of aromatic ring skeleton, which 
Table 3 Regression and ANOVA table

\begin{tabular}{|c|c|c|c|c|c|c|}
\hline Variance source & Sum of squares & Degree of freedom & Mean square & F value & $P$ value & Significance \\
\hline Model & 178.02 & 14 & 12.72 & 9.91 & $<0.0001$ & ** \\
\hline$A$ & 0.84 & 1 & 0.84 & 0.66 & 0.4313 & \\
\hline B & 8.20 & 1 & 8.20 & 6.39 & 0.0241 & * \\
\hline C & 28.92 & 1 & 28.92 & 22.54 & 0.0003 & ** \\
\hline $\mathrm{D}$ & 18.08 & 1 & 18.08 & 14.09 & 0.0021 & $* *$ \\
\hline$A B$ & 11.56 & 1 & 11.56 & 9.01 & 0.0095 & ** \\
\hline$A C$ & 23.81 & 1 & 23.81 & 18.56 & 0.0007 & $* *$ \\
\hline$A D$ & 7.08 & 1 & 7.08 & 5.51 & 0.0341 & * \\
\hline$B C$ & 0.029 & 1 & 0.029 & 0.023 & 0.8829 & \\
\hline $\mathrm{BD}$ & 1.00 & 1 & 1.00 & 0.78 & 0.3923 & \\
\hline$C D$ & 6.94 & 1 & 6.94 & 5.41 & 0.0355 & * \\
\hline$A^{2}$ & 50.18 & 1 & 50.18 & 39.10 & $<0.0001$ & $* *$ \\
\hline$B^{2}$ & 24.89 & 1 & 24.89 & 19.39 & 0.0006 & $* *$ \\
\hline$C^{2}$ & 8.65 & 1 & 8.65 & 6.74 & 0.0211 & * \\
\hline$D^{2}$ & 20.26 & 1 & 20.26 & 15.79 & 0.0014 & $* *$ \\
\hline Residual error & 17.97 & 14 & 1.28 & & & \\
\hline Missimulation & 17.89 & 10 & 1.79 & 90.11 & 0.0003 & ** \\
\hline Pure error & 0.079 & 4 & 0.020 & & & \\
\hline Total difference & 195.99 & 28 & & & & \\
\hline
\end{tabular}

*Difference was significant $(P<0.05)$

**Difference was extremely significant $(P<0.01)$

mainly comes from lignin and other compounds containing benzene ring.

After 2 days of fermentation, the relative absorption intensity of the absorption peak at $1680 \mathrm{~cm}^{-1}$ decreased obviously, and the relative absorption intensity and peak shape of the absorption peak at $1500 \mathrm{~cm}^{-1}$ changed greatly. Combined with the changes of these two absorption peaks, it is speculated that the lignin in the sample may be degraded greatly, and the degradation range of amide compounds is relatively large. On the 4th day of fermentation, the peak shape at $1500 \mathrm{~cm}^{-1}$ widened slightly, the relative absorption intensity changed little, and the relative absorption intensity of aromatic ring near $1680 \mathrm{~cm}^{-1}$ was slightly enhanced. It can be inferred that the degradation of cellulose and hemicellulose was relatively fast in the first 4 days of corn straw degradation by compound bacteria, thus increasing the relative proportion of lignin. $3010-2960 \mathrm{~cm}^{-1}$ represents the symmetric and antisymmetric stretching vibration peaks of $-\mathrm{CH}_{3},-\mathrm{CH}_{2}$, and $-\mathrm{CH}$ in carbohydrates, lignin, and aliphatic compounds. The absorption at 1330-1320 $\mathrm{cm}^{-1}$ belongs to the stretching vibration of $-\mathrm{OH}$ and comes from carbohydrates. After 6 days of fermentation, the relative absorption of the absorption peak at 3008 $\mathrm{cm}^{-1}$ was slightly weakened, and the relative absorption intensity of $1510-1500 \mathrm{~cm}^{-1}$, which represented the characteristic absorption peak of lignin, was also weakened, which indicated that part of cellulose and hemicellulose was continuously degraded, and the degradation range of lignin was also increased at this stage. The infrared spectrum of 8 days of fermentation changed little compared with that of 6 days of fermentation; it can be inferred that the reaction system has approached or reached the end point of fermentation, which is consistent with the results of the determination of the main components in the process of corn straw degradation.

Throughout the whole fermentation process, the shape of the absorption peak at $3450-3400 \mathrm{~cm}^{-1}$ gradually became sharp with the increase of fermentation time. This is mainly due to the fact that the hydroxyl groups in organic compounds form intermolecular hydrogen bonds in most cases, which exist in the form of association $\mathrm{OH}$, so the peak shape is easily shifted to the direction of low wavenumber due to the interference of amides and crystal water. With the progress of fermentation, the content of amide compounds in the substrate decreased gradually. Therefore, the proportion of hydroxyl groups of crystalline water or bound water in the inorganic complex became larger and larger, and the absorption peak became more and more sharp and shifted to the direction of high wavenumber. The absorption peak at $1740-1720 \mathrm{~cm}^{-1}$ is the $\mathrm{C}=\mathrm{O}$ stretching vibration of carboxylic acid lipids and ketones in organic compounds. With the progress of fermentation, some carboxylic 


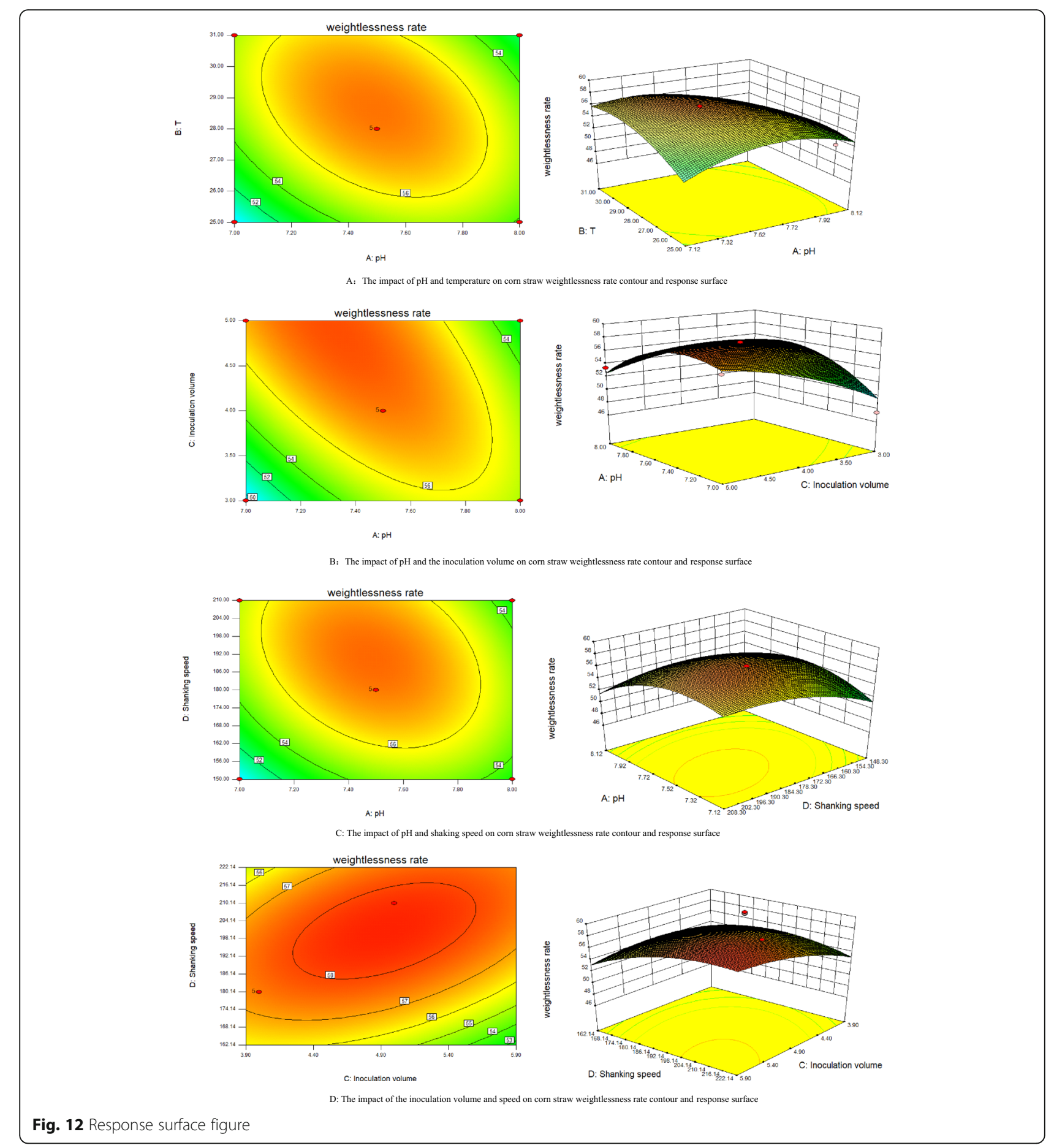

esters are hydrolyzed, and carboxyl groups form carboxylates with free cations. At the same time, it can also be inferred that there may be no ketones formed by oxidation in this fermentation process.

The study on the biodegradation of corn straw by infrared spectroscopy can reflect the decomposition changes of the main substances in corn straw to some extent, especially the changes of functional groups. Corn straw contains carbohydrates, lignin, and organosilicide. With the biodegradation of corn straw, the contents of hydroxyl, methyl, and methylene decreased gradually, indicating the degradation of cellulose and hemicellulose; carboxyl groups existed in the form of carboxylates in the process of fermentation, while some inorganic cations formed carbonates with $\mathrm{CO}_{2}$ formed by the degradation of carbohydrates such as cellulose and 
Table 4 Changes of components during fermentation

\begin{tabular}{llll}
\hline Fermentation days (days) & Cellulose content (\%) & Hemicellulose content (\%) & Lignin content (\%) \\
\hline 0 & $31.99 \mathrm{a}$ & $25.33 \mathrm{a}$ & $14.67 \mathrm{a}$ \\
1 & $30.02 \mathrm{a}$ & $24.57 \mathrm{a}$ & $14.03 \mathrm{a}$ \\
3 & $26.19 \mathrm{~b}$ & $18.52 \mathrm{~b}$ & $13.22 \mathrm{a}$ \\
5 & $21.70 \mathrm{c}$ & $13.94 \mathrm{c}$ & $11.58 \mathrm{~b}$ \\
7 & $14.72 \mathrm{~d}$ & $12.48 \mathrm{c}$ & $9.30 \mathrm{c}$ \\
9 & $12.52 \mathrm{e}$ & $11.33 \mathrm{c}$ & $9.12 \mathrm{C}$ \\
12 & $11.91 \mathrm{e}$ & $10.93 \mathrm{C}$ & $8.99 \mathrm{c}$ \\
15 & $10.88 \mathrm{e}$ & $10.87 \mathrm{c}$ & $8.82 \mathrm{c}$ \\
\hline
\end{tabular}

Note: Different lowercase letters means significant difference at 0.05 level

hemicellulose (Steiner et al. 1988). As for the polymerization of organic intermediates formed in the degradation process, because of the complexity, it is difficult to distinguish by infrared spectroscopy alone, which needs to be further analyzed by chemical and other instrumental analysis methods.

The infrared spectrum analysis of the biodegradation process of corn straw can not only reflect the decomposition changes of the main components in corn straw to a certain extent, but also reflect the general degradation law of each component. These laws reflected by infrared spectra are basically consistent with those reflected by the previous determination of the chemical content of the main components in the degradation process of corn straw.

\section{X-ray diffraction analysis}

For the study of fiber structure, the two-phase structure theory is generally adopted, that is, it is considered that the microstructure of fiber is composed of crystalline region and non-crystalline region. In the crystalline region, the macromolecules that make up the fiber are arranged in order, while in the non-crystalline region, the macromolecules are disordered. The parameters characterizing the fiber structure are generally polymerization degree, chain length, crystallinity and crystallinity distribution, orientation degree and orientation distribution,

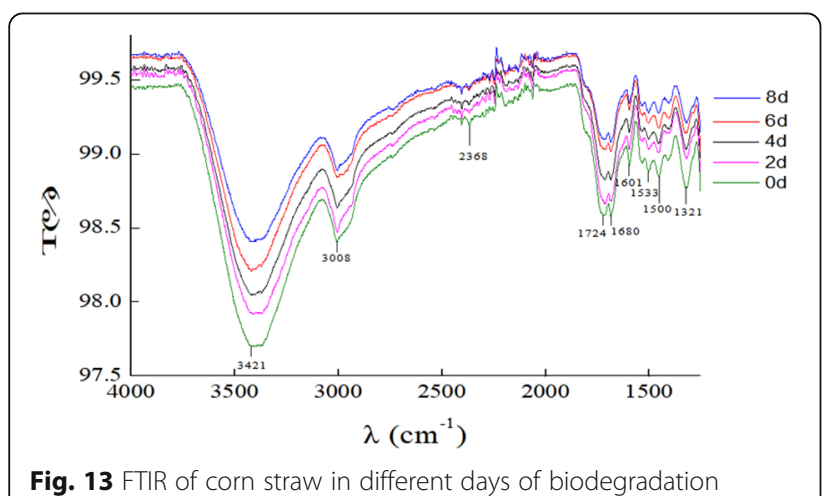

microstructure size, and so on, in which crystallinity is a commonly used index. Among the various methods for determining crystallinity, $\mathrm{x}$-ray diffraction is the most widely used, which has the characteristics of clear physical meaning and reliable data (Mo et al. 1988).

As can be seen from Table 5, the initial crystallinity of corn straw powder was $17.22 \%$, which basically showed an increasing trend in the first 6 days of fermentation, and the crystallinity increased to $21.72 \%$, which was significantly higher than the level of crystallinity before fermentation. The change trend of crystallinity shows that at the beginning of biodegradation, the in situ complex bacteria first act on the disordered non-crystalline region of cellulose in corn stalk, or the hydrolysis ability of cellulase secreted by in situ complex bacteria to the noncrystalline region of cellulose is greater than that of the crystalline region, and the rate of action on the noncrystalline region is higher than that on the crystalline region. At this stage, cellulase mainly hydrolyzes the non-crystalline region of corn straw cellulose and permeates into the crystalline region, thus increasing the crystallinity. When the fermentation lasted for 6 days, the crystallinity of corn straw decreased again, which indicated that the rate of cellulase acting on the crystallization region was relatively increased due to the infiltration of cellulase into cellulose macromolecules, so the crystallinity decreased at this stage. In the subsequent fermentation process, the crystallinity of corn

Table 5 Crystallinity of corn straw fermented by in situ compound bacteria for different time

\begin{tabular}{ll}
\hline Fermentation days (days) & Crystallinity (\%) \\
\hline 0 & 17.22 \\
2 & 19.55 \\
4 & 20.28 \\
6 & 21.72 \\
8 & 20.98 \\
10 & 21.03 \\
12 & 20.84 \\
\hline
\end{tabular}

The data in the table are the average of three measurements 
straw showed a fluctuating trend. At the end of fermentation, the crystallinity of corn straw decreased significantly to $20.84 \%$, but increased significantly compared with that before fermentation. This shows that there are both endonuclease and exonuclease components in the cellulase secreted by the in situ complex bacteria, which has an effect on both the crystalline region and the noncrystalline region of corn straw cellulose, and this effect is interactive and promotes each other. This makes the crystallinity of corn straw change periodically in the whole fermentation process. At the end of fermentation, the crystallinity increased significantly compared with that before fermentation, indicating that the degradation degree of non-crystalline region of corn straw cellulose by in situ complex bacteria was higher than that of crystalline region.

\section{Scanning electron microscopic observation on the degradation of corn straw}

As shown in Figs. 14 and 15, corn straw completely disintegrated under the action of in situ complex bacteria, which proved that the bacteria could degrade corn straw.

From the electron microscopic observation on the outer surface of corn straw at different degradation stages, it was found that the waxy silicified layer became thinner in the process of biodegradation, and the lower epidermis began to appear faintly until almost all of the waxy silicified layer disappeared. The lower epidermis is completely exposed. Combined with the results of infrared absorption spectrum analysis of silicide in the solid fermentation process of corn straw, it can be inferred that in the process of biodegradation, the organic silicon in corn straw gradually transformed into inorganic silicon, and the insoluble silicon gradually transformed into soluble silicon, which eventually led to the disappearance of a large number of silicified layer. The results of

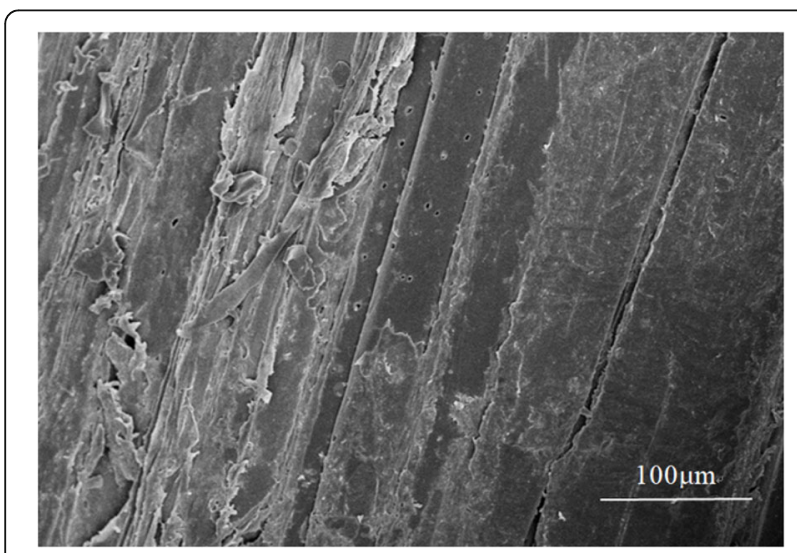

Fig. 14 Scanning electron microscope observation of corn straw before degradation

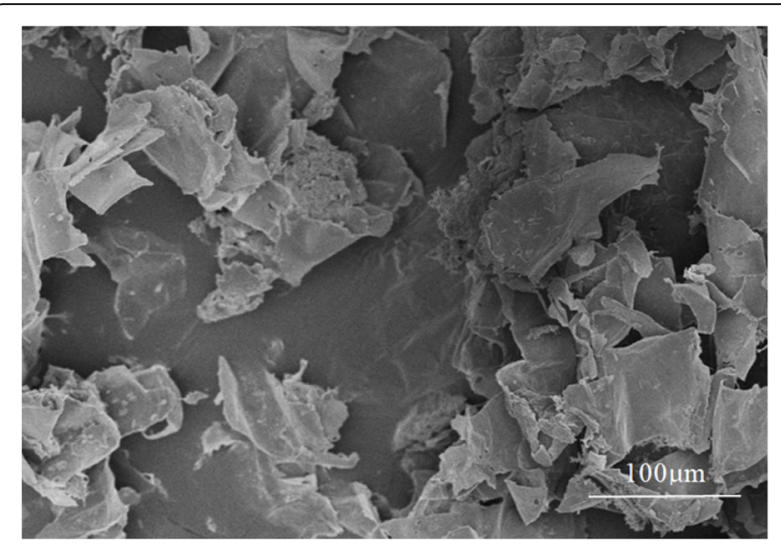

Fig. 15 Scanning electron microscope observation of corn straw after degradation

scanning electron microscope observation of corn straw further confirmed that the in situ complex bacteria had a strong ability to degrade and transform silicon in corn stalk. This excellent characteristic of this in situ complex microflora is extremely beneficial to the efficient degradation and feed utilization of corn straw.

\section{Application of corn straw after fermentation}

In this experiment, the microflora screened from the humus soil in the alpine area for many years was applied to this area, and the constructed in situ degradation microflora will not cause the exotic flora to destroy the microecology, which is of great significance in protecting the environment and preventing the invasion of alien species. In this experiment, three strains were flexibly selected to produce complementary enzymes for the main components of straw, so as to make the best use of things and have high economic value. In line with the principle of where to come from and where to use, the straw degradation bacteria with good effect can be made for different areas according to this test method, which has a good reference for the magnification experiment, and the degraded organic matter can be used as soil fertilizer, which has a good effect on the growth of crops planted in the second year. At present, this bacterial agent has been tested in the field in the experimental field of Heilongjiang Academy of Agricultural Sciences. In the later stage, we will make statistics after picking.

\section{Conclusion}

In this paper, corn straw composed of cellulose (31.99 $\%)$, hemicellulose (25.33\%), and lignin (14.67\%) was selected, and three strains of actinomycetes screened from the same sample were used. Through the determination of enzyme activity, strain Streptomyces sp. $\mathrm{G1}^{\mathrm{T}}$ had high decomposition ability to cellulose and hemicellulose but weak utilization ability to lignin. The decomposing 
ability of strain Streptomyces sp. $\mathrm{G}^{\mathrm{T}}$ to cellulose and hemicellulose was the strongest among the three strains, while the decomposing ability of strain Streptomyces sp. $\mathrm{G}^{\mathrm{T}}$ to lignin was the strongest among the three strains. The optimal process conditions obtained by single factor and response surface method are as follows: $\mathrm{pH}$ is 7 , temperature is $30^{\circ} \mathrm{C}$, inoculation amount is $5 \%$, rotational speed is $210 \mathrm{rpm}$, and the weight loss rate of straw is $60.55 \%$. The degradation efficiency was analyzed by Fourier transform infrared spectrometer, field emission scanning electron microscope, and X-ray diffractometer. The results showed that the in situ degradation bacteria constructed in this paper had excellent decomposing effect on corn straw. Further research should be carried out magnification test, in order to make the in situ complex flora adapt to various climatic temperatures, through the adaptive evolution of microorganisms, to achieve the best application effect.

\section{Acknowledgements}

The author Xiujie Gong thankfully acknowledge the funding support received from Heilongjiang Provincial Science and Technology Planning Institute (NO. YS19B02), China.

\section{Authors' contributions \\ Xiujie Gong performed and analyzed the experimental research work and primarily drafted the manuscript. Hongtao Zou designed and supervised this work. Chunrong Qian configured the manuscript. Yang Yu, Yubo Hao, and Liang Li helped to analyze the experimental research work. Qiuju Wang, Yubo Jiang, and Juntao Ma helped to finalize the manuscript. The authors read and approved the final manuscript.}

\section{Funding}

This work was supported by Heilongjiang Provincial Science and Technology Planning Institute (NO. YS19B02), China. Agricultural Science and technology innovation across the project special (NO.HNK2019CX12), China.

\section{Availability of data and materials}

All data generated or analyzed during this study are included in this article.

\section{Ethics approval and consent to participate}

Not applicable.

\section{Consent for publication}

Informed consent was obtained from all individual participants included in the study.

\section{Competing interests}

The authors declare that they have no competing interests.

\footnotetext{
Author details

${ }^{1}$ College of Land and Environment, Shenyang Agricultural University, No. 120, DongLing Road, Shenhe District, Shenyang 110866, People's Republic of China. ${ }^{2}$ Institute of Farming and Cultivation, Heilongjiang Academy of Agricultural Sciences, No. 368 Xuefu Road, Nangang District, Harbin 150086, People's Republic of China. Institute of Soil Fertilizer and Environment Resources, Heilongjiang Academy of Agricultural Sciences, No. 368 Xuefu Road, Nangang District, Harbin 150086, People's Republic of China. ${ }^{4}$ Institute of Biotechnology, Heilongjiang Academy of Agricultural Sciences, No. 368 Xuefu Road, Nangang District, Harbin 150086, People's Republic of China.
}

Received: 27 June 2020 Accepted: 1 October 2020

Published online: 31 October 2020

\section{References}

Aarti C, Khusro A, Agastian P (2018) Carboxymethyl cellulase production optimization from Glutamicibacter arilaitensis strain ALA4 and its application in lignocellulosic waste biomass saccharification. Prep Biochem Biotechnol 48:853-866. https://doi.org/https://doi.org/10.1080/10826068.2018.1514513

Aiba S, Humphrey AE, Millis NF (1973) Biochem engineering. Academic Press, New York

Bai S, Ravi KM, Mukesh KDJ, Balashanmugam P, Balakumaran MD, Kalaichelvan PT (2012) Cellulase production by Bacillus subtilis isolated from cow dung. Arch Appl Sci Res 4:269-279

Brock TD, Madigan MT (1988) Biology of microorganisms. Prentice-Hall, New Jersey

Cao GL (2010) Study on hydrogen production bacteria and hydrogen production performance of efficient utilization of corn straw. (Doctoral dissertation, Harbin Institute of Technology)

Chen CL (2002) Present situation and prospect of agricultural waste resource utilization technology. Environ Protect Xinjiang 24:22-25

Chen W, Lu WF, Duan BW, Wassmann R, Lantin RS (2002) Effect of rice straw returning on methane emission from late rice field. J Soil 02:27-33

Denison DA, Koehn RD (1977) Cellulase activity of Poronia oedipus. Mycologia 69 $592-603$

Gao JQ (2006) Study on the degradation characteristics of rice straw substrate by mushroom. Doctoral dissertation, Southwest University

Han L, Yan QJ, Liu XY, Hu JY (2002) Crop straw resources and their utilization in China. J Agric Eng 018:87-91

Klemm D, Schmauder HP, Heinze T (2005) Biopolymers. In: Vandamme E, Beats S, Steinb Chel A (eds) Cellulose. Wiley, Weinheim. https://doi.org/https://doi. org/10.1002/3527600035.bpol6010

Liou RM, Huang SN, Lin CW, Chen SH (2003) Methane emission from fields with three various rice straw treatments in Taiwan paddy soils. J Environ Sci Health B 38:511-527. https://doi.org/. https://doi.org/10.1081/PFC-120021670

Liu MR, Fu SY, Zhan HY, Liu H, Wu H, Luo X (2008) Study on solid fermentation conditions of laccase production by Streptomyces pilosula and lignin degradation of rice straw by laccase solution. Guangdong Provincial Papermaking member Congress and academic Annual meeting. China Papermaking Society

Lu F, Wang XK, Han B, Ouyang ZY, Zheng H (2010) Modeling the greenhouse gas budget of straw returning in China: feasibility of mitigation and countermeasures. Ann N Y Acad Sci 1195:107-130. https://doi.org/https://doi. org/10.1111/j.1749-6632.2009.05408.x

Mo ZS, Zhang HF (1988) The crystallinity of polymer was determined by X-ray diffraction. Polymer Mat Sci Eng 003:9-20

Octave S, Thomas D (2009) Biorefinery: toward an industrial metabolism. Biochimie 91:659-664. https://doi.org/https://doi.org/10.1016/j.biochi.2009.03. 015

Qiang J (2006) Utilization mode and development countermeasure of straw resources. Energy Saving Technol 24:564-565

Roy RN, Sen SK (2013) Fermentation studies for the production of dibutyl phthalate, an ester bioactive compound from Streptomyces albidoflavus MTCC 3662 using low-priced substrates. Jordan J Biol Sci 6:177-181

Russell JB, Muck RE, Weimer PJ (2009) Quantitative analysis of cellulose degradation and growth of cellulolytic bacteria in the rumen. FEMS Microbiol Ecol 67:183-197. https://doi.org/https://doi.org/10.1111/j.1574-6941. 2008.00633.x

Sabine W, Stephan S, Ralf C (2001) Bacterial populations colonizing and degrading rice straw in anoxic paddy soil. Appl Environ Microbiol 67:13181327. https://doi.org/https://doi.org/10.1128/AEM.67.3.1318-1327.2001

Sreena CP, Sebastian D (2018) Augmented cellulase production by Bacillus subtilis strain MU S1 using different statistical experimental designs. J Genet Eng Biotechnol 16:09-16. https://doi.org/https://doi.org/10.1016/j.jgeb.2017. 12.005

Sreena CP, Vimal KP, Sebastian D (2016) Production of cellulases and xylanase from Bacillus subtilis MU S1 isolated from protected areas of Munnar wildlife division. J Microbiol Biotechnol Food Sci 5:500-504. https://doi.org/https:// doi.org/10.15414/jmbfs.2016.5.6.500-504

Steiner W, Sattler W. Esterbauer H (1988) Adsorption of Trichoderma reesei cellulase on cellulose: experimental data and their analysis by different 
equations. Biotechnol Bioeng 32:853-865. https://doi.org/https://doi.org/10. 1002/bit.260320703

Sukumaran RK, Singhania RR, Pandey A (2005) Microbial cellulases-production, application and challenges. J Sci Ind Res 64:832-844

Sun P, Gao JL, Mao XJ, Zhao XH, Sun JG, Mengzhu LUM (2016) Lentibacillus populi sp. nov. a moderately halophilic, endophytic bacterium isolated from a poplar tree, and emended description of the genus Lentibacillus. Int I Syst Evol Microbiol 66:5281-5287. https://doi.org/https://doi.org/10.1099/ijsem.0. 001508

Teather RM, Wood PJ (1982) Use of Congo red-polysaccharide interactions in enumeration and characterization of cellulolytic bacteria from the bovine rumen. Appl Environ Microbiol 43:777-780

Thomas L, Ram H, Singh VP (2018) Inducible cellulase production from an organic solvent tolerant bacillus sp. SV1 and evolutionary divergence of endoglucanase in different species of the genus bacillus. Braz J Microbiol 49: 429-442. https://doi.org/https://doi.org/10.1016/j.bjm.2017.05.010

Wanderley KJ, Torres FAG, Moraes LMP, Ulhoa CJ (2004) Biochemical characterization of a-amylase from the yeast Cryptococcus flavus. FEMS Microbiol Lett 231:165-169. https://doi.org/https://doi.org/10.1016/S03781097(03)00955-8

Watanabe H, Tokuda G (2010) Cellulolytic systems in insects. Annu Rev Entomol 55:609-632. https://doi.org/https://doi.org/10.1146/annurev-ento-112408085319

Xu H, Cai ZC, Jia ZJ, Hetian ZX (2001) Effect of straw returning time on ch4 emission from rice field in previous season. J Agricult Environ Sci 020:289292

Yin LJ, Huang PS, Lin HH (2010) Isolation of cellulase-producing bacteria and characterization of the cellulase from the isolated bacterium Cellulomonas sp. YJ5. J Agric Food Chem 58:9833-9837. https://doi.org/https://doi.org/10. 1021/jf1019104

Younis MAM, Hezayen FF, Nour-Eldein MA, Shabeb MSA (2010) Optimization of cultivation medium and growth conditions for Bacillus subtilis KO strain isolated from sugar cane molasses. Am Euras J Agric Environ Sci 7:31-37

Zhang Y (2009) Comparative analysis on the benefits of the utilization of straw resources "5f" in China. China Agricult Bull 23:55-61

Zhong HP, Yue YZ, Fan JW (2003) Crop straw resources and their utilization in China. Resour Sci 04:64-69

\section{Publisher's Note}

Springer Nature remains neutral with regard to jurisdictional claims in published maps and institutional affiliations.

Ready to submit your research? Choose BMC and benefit from:

- fast, convenient online submission

- thorough peer review by experienced researchers in your field

- rapid publication on acceptance

- support for research data, including large and complex data types

- gold Open Access which fosters wider collaboration and increased citations

- maximum visibility for your research: over $100 \mathrm{M}$ website views per year

At $\mathrm{BMC}$, research is always in progress.

Learn more biomedcentral.com/submissions 